\title{
Scale-Dependent Habitat Selection of Nesting Great Egrets and Snowy Egrets
}

\author{
Eric D. Stolen ${ }^{1,2}$, Jaime A. Collazo ${ }^{3}$ AND H. Franklin Percival ${ }^{4}$ \\ ${ }^{1}$ Department of Wildlife Ecology and Conservation, University of Florida, Gainesville, FL 32611-0430, USA \\ ${ }^{2}$ Current address: Dynamac Corp., Mail Code: DYN-2, Kennedy Space Center, FL 32899, USA \\ Internet: eric.d.stolen@nasa.gov
}

${ }^{3}$ U.S. Geological Survey, North Carolina Cooperative Fish and Wildlife Research Unit, Department of Zoology, North Carolina State University, Raleigh, NC 27695-7617, USA

${ }^{4}$ U.S. Geological Survey, Florida Cooperative Fish and Wildlife Research Unit, Department of Wildlife Ecology and Conservation, University of Florida, Gainesville, FL 32611-0485, USA

\begin{abstract}
Foraging habitat selection of nesting Great Egrets (Ardea alba) and Snowy Egrets (Egretta thula) was investigated within an estuary with extensive impounded salt marsh habitat. Using a geographic information system, available habitat was partitioned into concentric bands at five, ten, and $15 \mathrm{~km}$ radius from nesting colonies to assess the relative effects of habitat composition and distance on habitat selection. Snowy Egrets were more likely than Great Egrets to depart colonies and travel to foraging sites in groups, but both species usually arrived at sites that were occupied by other wading birds. Mean flight distances were $6.2 \mathrm{~km}(\mathrm{SE}=0.4, \mathrm{~N}=28$, range $1.8-10.7 \mathrm{~km})$ for Great Egrets and $4.7 \mathrm{~km}(\mathrm{SE}=0.48, \mathrm{~N}=31$, range $0.7-12.5 \mathrm{~km})$ for Snowy Egrets. At the broadest spatial scale both species used impounded (mostly salt marsh) and estuarine edge habitat more than expected based on availability while avoiding unimpounded (mostly fresh water wetland) habitat. At more local scales habitat use matched availability. Interpretation of habitat preference differed with the types of habitat that were included and the maximum distance that habitat was considered available. These results illustrate that caution is needed when interpreting the results of habitat preference studies when individuals are constrained in their choice of habitats, such as for central place foragers. Received 23 June 2006, accepted 16 December 2006.

Key words.- - foraging habitat, habitat selection, flight distance, scale, Great Egret, Ardea alba, Snowy Egret, Egretta thula, impounded habitat, coastal wetlands.
\end{abstract}

Waterbirds 30(3): 384-393, 2007

Populations of colonial nesting herons and egrets (hereafter ardeids) face a variety of threats, including isolation and alteration of coastal wetlands (Erwin et al. 2005). In some regions coastal wetlands are isolated from estuaries by impoundments that are created to control wetland hydrology or function (Brockmeyer et al. 1997). Wetland alteration can affect the availability and quality of foraging habitat near colonies (Erwin et al. 2005) and these factors affect breeding ardeids (Fasola and Barbieri 1978; Ogden 1994; Gibbs and Kinkel 1997; Jakubas 2004). Thus, ardeid nesting colonies provide a focal point for protecting and managing surrounding foraging habitat (Ogden 1994; Kushlan 1997; Lombardini et al. 2001) and a useful indicator of anthropogenic impacts to wetlands (Stolen et al. 2005). However, for these biological elements to serve a conservation function, information on the factors influencing selection of foraging habitat is needed.
The objective of this study was to quantify foraging habitat use by Great Egrets (Ardea alba) and Snowy Egrets (Egretta thula) nesting on spoil islands within the northern part of the Indian River Lagoon estuary in central Florida (USA). This site contains extensive coastal impoundments and a large population of colonial nesting ardeids. We compared patterns of foraging habitat use with availability at three scales to assess the relative importance of impounded, unimpounded and estuarine edge wetland habitats to nesting Great Egrets and Snowy Egrets in this system. For each scale, we tested whether nesting wading birds selected among available habitats for foraging. Because of uncertainty over the suitability of freshwater forested wetland as foraging habitat for these species, we examined the effect of including or excluding forested wetlands within available habitat, on the interpretation of habitat selection patterns. We also measured foraging 
flight distances and flight speed, because these parameters can influence colony and foraging site selection (e.g., Gibbs 1991). Finally, we report information on the size of foraging groups and of flocks leaving the colonies because levels of foraging sociability in egrets varies widely among sites (Caldwell 1981; Erwin 1983; Kersten et al. 1991; Hafner et al. 1993; Master et al. 1993; Stolen 2006) and these attributes may influence resource selection at local levels (Dall et al. 2005).

\section{METHODS}

\section{Study Site}

Nesting wading birds were followed to foraging sites from three mixed-species colonies located within the boundaries of the Kennedy Space Center-Merritt Island National Wildlife Refuge (hereafter KSC/MINWR; Fig. $1)$. The 55,000 ha KSC/MINWR is located in the northern portion of the Indian River Lagoon system, a subtropical estuary comprised of the Indian River, Banana River and Mosquito Lagoon that stretches for ca. 250 $\mathrm{km}$ from Ponce de Leon Inlet to Jupiter Inlet. The northern portion of the Indian River Lagoon estuary is isolated from ocean inlets and has very low diurnal tidal changes (less than one cm; Smith 1987). In this region,

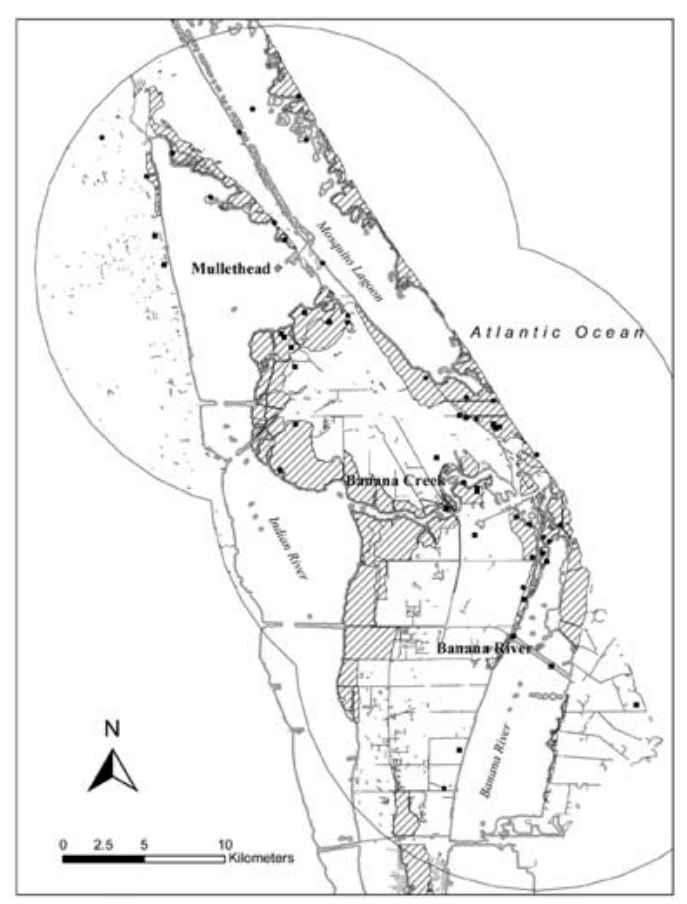

Figure 1. Foraging locations of Great Egrets (circles) and Snowy Egrets (squares) followed from three colonies (targets) in the northern Indian River Lagoon estuary, Florida. Hatched areas show locations of impoundments. seasonal and wind-driven water level fluctuations are of much greater importance (Smith 1993). This estuary is an important site for wading birds on the southeastern Atlantic coast of North America (Schikorr and Swain 1995; Sewell et al. 1995). KSC/MINWR supports a large wading bird population that utilizes freshwater and impounded salt marsh habitats for feeding, roosting, and nesting (Smith and Breininger 1995; Stolen et al. 2002). This region has extensive salt marsh habitat fringing the estuary; however, almost all salt marsh habitat in the northern Indian River Lagoon estuary was impounded for mosquito control by the 1970s (Brockmeyer et al. 1997). Within $15 \mathrm{~km}$ of the three focal colonies there were 90 impoundments (average size 141 ha, total area $12,716 \mathrm{ha}$ ) adjacent to the estuary. Habitat within impoundments is predominantly a heterogeneous mixture of open water and vegetated cover types, with tall marsh grass (e.g., Spartina bakeri) and short marsh vegetation (e.g., Distichlis spicata, Batis maritima) predominating in vegetated areas (Schmalzer 1995). Efforts are currently underway to reconnect hydrologically isolated impounded wetlands of the northern Indian River Lagoon estuary (Brockmeyer et al. 1997).

Nesting colonies on KSC/MINWR have been monitored since 1987 (Stolen et al. 2002). For this study, focal colonies were selected as the largest colony within each of three broad north-south strata of KSC/MINWR (Fig. 1 ). Two of the colonies occurred on spoil islands located near dredged navigation channels (Mullethead Island and Banana River) and the third was on a large naturally occurring island which had been drag-line ditched prior to 1970 for mosquito control (Banana Creek). Mullethead Island has had nesting colonies in every year since monitoring began in 1987; Banana Creek (also called Big Island) has had colonies since 1993 and Banana River (also called Banana River colony \#14) since 1994 (E. D. Stolen, unpublished data).

\section{Foraging Flight Observations}

Great Egrets and Snowy Egrets were followed from their nests to their foraging locations (hereafter referred to as "follows"). Follows were conducted using a helicopter (Bell UH-1) between sunrise and five hours after sunrise. The helicopter was hovered $300 \mathrm{~m}$ horizontal distance from each colony at an altitude of $150 \mathrm{~m}$ until a bird was observed leaving the colony. The helicopter remained at least $300 \mathrm{~m}$ behind the bird while it was followed. Once a bird landed at a foraging location, a GPS position was recorded for the location using a Garmin 12 channel GPS receiver, and the habitat type was noted. Habitat types were defined as open water (patches of at least two $m$ of no emergent vegetation) or vegetated. A site was considered occupied if at least one other wading bird occurred within $30 \mathrm{~m}$ of the landing location; in these cases the landing bird was considered to have joined an aggregation. The identity of other wading birds within $100 \mathrm{~m}$ of the subject's landing location was recorded. If the subject left the colony with others or joined a group in flight, an attempt was made to note the landing position of all members of the group, but often this was not possible because the subject bird would continue flying. In these cases, only information about the subject bird was recorded.

\section{Habitat Use Analysis}

GPS positions of landing sites were recorded in a GIS for calculation of distances and habitat use analysis. 
Analysis was conducted using the software packages ArcView 3.2 and ArcMap 8.2 (ESRI, Redlands, California). Quantification of available habitat was based on a land cover map produced by the St. Johns River Water Management District using photo interpretation of 1:40,000 color-infrared aerial photography taken in 1999 (Anonymous 2002). To calculate the total amount of available habitat, three concentric distance-buffers of five, ten, and $15 \mathrm{~km}$ radii were produced around each of the three colonies, and the ensuing circular regions were combined into a single polygon where the colony-specific distance-buffers overlapped. These distances were chosen to include all wetland habitats available within the range of flight distances of Great Egrets and Snowy Egrets observed in previous studies in Florida (e.g., Frederick and Collopy 1989; Bancroft et al. 1994).

Wetland habitats within the distance-buffers were reclassified into three groups: impounded, estuarine edge, and unimpounded. Using the GIS, all wetland habitats occurring within the perimeter dikes surrounding impoundments were classified as impounded, and the areas of these wetlands within each distance-buffer were summed. This habitat was located exclusively along the estuarine edge (Fig. 1) and consisted of predominantly salt marsh, but also included mangrove and fresh water forested wetlands (Table 1). Some impoundments had perimeter dikes that were recently removed or breeched for restoration of the habitat (Brockmeyer et al. 1997); these areas were included in the total of impounded habitat for two reasons. First, most restoration was completed within the previous five years and all restored areas had experienced long periods of impoundment prior to reconnection. Thus restored sites may not yet have returned to functioning as unimpounded wetlands. Second, the total area of wetlands within these impoundments was small (less than five percent) compared with the total for all wetlands within the $15-\mathrm{km}$ buffer. If these wetlands had been included in another category, they would have slightly increased the expected number of birds foraging in that habitat and decreased the expected number in impounded salt marsh. Thus, inclusion of these wetlands within the impounded salt marsh area was conservative when evaluating the hypothesis of preference for impounded salt marsh (because it increased the predicted proportion of birds foraging within impoundments, thus making it harder to conclude that birds selected this habitat).

Estuarine edge habitat was defined as shallow areas along the edges of the three large lagoon basins in the study area: the Indian River, The Banana River, and the Mosquito Lagoon (Fig. 1). To calculate the area of estuarine edge accessible to wading birds, different buffer distances were used to quantify habitat separately for Great Egrets and Snowy Egrets. Distances for speciesspecific buffer widths were determined by examining the distribution of distances at which birds were observed during long-term foraging habitat use surveys of estuarine edge, which have been conducted monthly on KSC/MINWR since 1987 (Stolen et al. 2002). Distances were chosen that included $95 \%$ of all observations for each species as follows: Great Egret $100 \mathrm{~m}(\mathrm{~N}=5804)$, Snowy Egret $40 \mathrm{~m}(\mathrm{~N}=3404)$.

The area of unimpounded wetlands was calculated by first summing the areas of all unimpounded wetland land cover types within each distance buffer, excluding the interiors of lakes and rivers. Then, to represent available foraging habitat within open water of lakes and rivers, a one-m buffer was generated within all lakes and rivers and the area added to the total for unimpounded wetlands. Because the 2000 Land Cover and Land Use map did not map wetlands less than 0.2 ha, polygons from a 1990 Land Cover map of KSC/MINWR which included such features were used (Larson 1992). Because this map did not extend far enough west to include the entire study area, these features were mapped using 1999 orthorectified color infrared photography

Table 1. Areas of land cover types (ha) within estuarine edge, impounded and unimpounded wetland habitats for three flight-radius distances from focal nesting colonies in the northern Indian River Lagoon estuary, Florida. The proportion of forested and unforested habitat within each distance is also shown for Great Egrets and Snowy Egrets.

\begin{tabular}{|c|c|c|c|}
\hline Summary & $5 \mathrm{~km}$ & $10 \mathrm{~km}$ & $15 \mathrm{~km}$ \\
\hline Total area within distance radius of colonies & 23,442 & 82,162 & 152,063 \\
\hline Area estuary edge 40 m buffer (Snowy Egret) & 686 & 1,697 & 2,375 \\
\hline Area estuary edge 100 m buffer (Great Egret) & 1,532 & 3,785 & 5,278 \\
\hline Area impounded mangrove wetlands & 265 & 850 & 1,143 \\
\hline Area impounded freshwater forested wetlands & 562 & 1,419 & 1,950 \\
\hline Area impounded freshwater marsh & 142 & 440 & 700 \\
\hline Area impounded salt marsh & 1,580 & 4,820 & 5,769 \\
\hline Area impounded open water within salt marsh & 993 & 2,561 & 3,034 \\
\hline Area unimpounded canal and lake $1 \mathrm{~m}$ buffer & 19 & 59 & 78 \\
\hline Area unimpounded mangrove wetlands & 255 & 400 & 478 \\
\hline Area unimpounded freshwater forested wetlands & 1,754 & 6,064 & 10,465 \\
\hline Area unimpounded freshwater marsh & 530 & 2,184 & 3,262 \\
\hline Area unimpounded salt marsh & 131 & 897 & 1,238 \\
\hline Area unimpounded open water within salt marsh & 20 & 106 & 117 \\
\hline Proportion Great Egret habitat with forest & 0.36 & 0.37 & 0.42 \\
\hline Proportion Great Egret habitat without forest & 0.64 & 0.63 & 0.58 \\
\hline Proportion Snowy Egret habitat with forest & 0.41 & 0.41 & 0.46 \\
\hline Proportion Snowy Egret habitat without forest & 0.59 & 0.59 & 0.54 \\
\hline
\end{tabular}


(Anonymous 1999). The unimpounded habitat type was predominantly composed of freshwater wetlands (Table 1). It was not clear whether or not to include forested wetlands within available ardeid foraging habitat. Although both Great Egrets and Snowy Egrets will use freshwater forested wetlands (Palmer 1962; Hancock and Kushlan 1984) it is unclear how important this habitat is to either species. Thus habitat use analysis was conducted both with and without these wetlands included, to assess the effect of uncertainty over their use on interpretation of habitat selection. Presenting results of analysis both with and without forested wetlands is also useful because planners may consider wetlands of all types as a unit when making management decisions concerning wading bird foraging habitat (i.e., lumping forested and unforested wetlands together).

Habitat selection analysis was conducted using a resource selection ratio: $\mathrm{w}_{\mathrm{i}}=$ [proportion of habitat $\mathrm{i}$ used]/[proportion of habitat $i$ available] (Manly et al. 2002). This ratio measures the relative preference between habitat types allowing comparison of preferences between habitats that is not affected by what other types are included. For each analysis, the resource selection ratio of the observed bird use of each of the three habitat categories (impounded wetland, unimpounded wetland and estuarine edge) was calculated for each distance buffer (five, ten, and $15 \mathrm{~km}$ ) for each species. Thus, six different scenarios were examined for each species (i.e., five $\mathrm{km}$ radius with forested wetlands included, five $\mathrm{km}$ radius without forested wetlands included, etc.). Selection ratios were evaluated to determine if they differed from 1.0 and thus exhibited selection $\left(\mathrm{w}_{\mathrm{i}}>1.0\right)$ or avoidance $\left(\mathrm{w}_{\mathrm{i}}<1.0\right)$ of the habitat type, using a Bonferroni partitioning of experiment-wise $\alpha=$ 0.05 . Manly's standardized selection ratio was calculated as $\mathrm{B}_{\mathrm{i}}=\mathrm{w}_{\mathrm{i}} /$ [sum of $\mathrm{w}_{\mathrm{i}}$ for each habitat type]; this measure can be interpreted as giving the estimated probability of habitat i being used if all habitat types were equally available (Manly et al. 2002). We also tested whether each selection ratio for each habitat type differed from the other two using methods presented in Manly et al. (2002) for each habitat use scenario. In several cases a group of birds was followed from a colony to a single foraging site and in these cases only one location was included in the analysis in keeping with the assumption that individuals observed are independent (Manly et al. 2002). Observations of individuals followed on different days were assumed to be independent. A Chi-square test was used to compare the frequency of use of habitat categories between species (Conover 1980).

Distance traveled between the nest and the foraging site was calculated with the GIS. Due to the difficulty of observing birds exactly as they left nests, colony centers were used for the origins of all foraging flights. Duration of foraging flight was calculated as the duration between the detection of the bird leaving the colony and the time the bird landed at the foraging site. This usually resulted in a few seconds being truncated between when a bird left a nest and when it was detected leaving a colony. The average flight speed was calculated as the straight line distance traveled divided by the time of travel; this is a minimum estimate because many birds changed headings during travel resulting in actual flight distances being greater than straight line distances calculated in the GIS. The Mann-Whitney U-test was used to compare the sizes of groups joined, distances and flight speed between species (Conover 1980).
RESULTS

Foraging Flight Characteristics

Thirty Great Egrets and 54 Snowy Egrets were followed from three nesting colonies between April 7 and June 9, 2000 (on seven days for Great Egret and on eight days for Snowy Egret). This period was after most nests were initiated and adults could be expected to be provisioning chicks (E. Stolen, unpublished data). Great Egrets landed at 28 and Snowy Egrets at 31 unique foraging locations (Fig. 1). The destination of three Snowy Egrets and one Great Egret could not be determined. There were still many active nests in all three colonies when follows ended. The maximum numbers of nests counted in the entire study area were 202 Great Egrets and 165 Snowy Egrets in eleven colonies (E. Stolen, unpublished data).

Over half of all Snowy Egrets followed left the colonies in groups (eight of 31 follows). Most of these groups were composed of conspecifics except in two cases when Snowy Egrets left the colony with a Great Egret. The mean and median group size of Snowy Egrets that left colonies in groups was 3.9 and 2.5 respectively. In addition, four of the Snowy Egrets followed (two single birds and a group of two) joined groups in flight. Most Snowy Egrets that left colonies in groups or joined groups in flight arrived at foraging sites with those groups (two Snowy Egrets followed did not). All but three of the Snowy Egrets followed arrived at foraging sites that were occupied by mixed-species foraging aggregations; one arrived at a site occupied by a lone Snowy Egret and two arrived at unoccupied sites. The mean and median size of mixed-species foraging aggregations joined by Snowy Egrets is summarized in Table 2. The distance, duration and speed of all Snowy Egret foraging flights followed are summarized in Table 3.

Seven of the 30 Great Egrets followed left colonies in groups (five of 28 separate follows). Two left in groups composed of another single Great Egret, the others with Snowy Egrets. The mean and median group size of Great Egrets that left colonies in groups was 
Table 2. Summary of the sizes of foraging aggregations joined by Great Egrets and Snowy Egrets followed from three colonies in the northern Indian River Lagoon estuary, Florida. Entries in the table for each habitat are mean number $( \pm \mathrm{SE})$ of birds in aggregations on the first row, followed by median on the next row.

\begin{tabular}{|c|c|c|c|c|c|c|c|c|}
\hline Species & Impounded & $\mathrm{N}$ & Freshwater & $\mathrm{N}$ & $\begin{array}{l}\text { Estuarine } \\
\text { edge }\end{array}$ & $\mathrm{N}$ & $\begin{array}{l}\text { Combined } \\
\text { (all sites) }\end{array}$ & $\mathrm{N}$ \\
\hline Great Egret & $\begin{array}{l}112.0(33.1) \\
107.5\end{array}$ & 12 & $\begin{array}{l}11.0(9.5) \\
2\end{array}$ & 3 & $\begin{array}{l}6.2(3.4) \\
3\end{array}$ & 5 & $\begin{array}{l}70.4(22.8) \\
10.5\end{array}$ & 20 \\
\hline Snowy Egret & $\begin{array}{l}256.1(82.1) \\
100\end{array}$ & 19 & $\begin{array}{l}24.9(8.0) \\
30\end{array}$ & 7 & $\begin{array}{l}47.5(12.5) \\
47.5\end{array}$ & 2 & $\begin{array}{l}183.4(58.9) \\
47\end{array}$ & 28 \\
\hline
\end{tabular}

2.4 and 2, respectively. No Great Egret followed joined a group in flight. Only three of the seven Great Egrets that departed colonies in groups arrived at foraging sites with those groups (two of the five follows). Twenty-two of the 30 Great Egrets followed arrived at foraging sites that were occupied by foraging aggregations (20 of 28 follows); 14 of the aggregations were composed of mixed-species foraging aggregations while six were composed of only conspecifics. The mean and median size of mixed-species foraging aggregations joined by Great Egrets is summarized in Table 2. The distance, duration and speed of the Great Egret foraging flights followed are summarized in Table 3 .

Over all groups followed, aggregations joined by Great Egrets were significantly smaller than were those joined by Snowy Egrets (Mann-Whitney U Test, $\mathrm{Z}=-2.011, \mathrm{P}=$ $0.044)$. Great Egrets flew greater distances to foraging locations than did Snowy Egrets (Mann-Whitney $\mathrm{U}$ test, $\mathrm{Z}=2.474, \mathrm{P}=0.013$ ); the duration of trips from colonies to foraging sites were not statistically different between species (Mann-Whitney $\mathrm{U}$ test, $\mathrm{Z}=$ 1.689 , n.s.).

\section{Habitat Use Analysis}

There was no difference in the frequency of use of the three habitat types between species $\left(\chi_{2}^{2}=2.35\right.$, n.s. $)$. Great Egrets that landed in impounded sites landed exclusively in open water and always joined a foraging aggregation. Similarly, most impounded sites in which Snowy Egrets landed were in open water (14 of the 19). Snowy Egrets landing in impoundments always joined aggregations of other wading birds. The size of aggregations joined by birds landing in impounded sites was larger than that for other habitats combined (Table 2) and the difference was significant for both Great Egret (Mann-Whitney $\mathrm{U}$ Test, $\mathrm{Z}=-1.987, \mathrm{P}=0.047$ ) and Snowy Egret (Mann-Whitney U Test, $\mathrm{Z}=-2.02, \mathrm{P}=$ 0.043 ). Four of the unimpounded sites at which Great Egrets landed were open water while one was vegetated. Similarly, six of the unimpounded sites at which Snowy Egrets landed were open and two were vegetated. All but two of the twelve estuarine edge sites at which Great Egrets and Snowy Egrets landed were in open water up to $40 \mathrm{~m}$ from the shoreline edge. The two remaining sites

Table 3. Summary of flight distance, duration and speed for Great Egrets and Snowy Egrets followed from three colonies in the northern Indian River Lagoon estuary, Florida. Values in parentheses are standard errors.

\begin{tabular}{lcccc}
\hline \hline Measure & Great Egret & $\mathrm{N}$ & Snowy Egret & $\mathrm{N}$ \\
\hline Average distance $(\mathrm{km})$ & $6.2(0.46)$ & 28 & $4.7(0.48)$ & 31 \\
Median Distance (km) & 5.6 & 28 & 4.2 & 31 \\
Distance range (km) & $1.8-10.7$ & 28 & $0.7-12.5$ & 31 \\
Average duration (min) & $10.3(1.0)$ & 28 & $8.0(0.92)$ & 30 \\
Median Duration (min) & 9.4 & 28 & 6.5 & 30 \\
Duration range $(\mathrm{min})$ & $2.0-22.8$ & 28 & $1.0-18.8$ & 30 \\
${\text { Average speed }(\mathrm{km} / \mathrm{hr})^{\mathrm{a}}}^{\mathrm{a}}$ & $38.8(1.6)$ & 28 & $38.2(1.7)$ & 30 \\
\hline
\end{tabular}

${ }^{a}$ Average speed calculated from duration and distance of each flight. 
(one for each species) were located on small unimpounded islands of low marsh vegetation located away from the mainland.

The proportion of total suitable habitat within flight distances from colonies that was forested increased with flight radius while the proportion that was unforested decreased (Table 1). Fifty-eight unique foraging locations were identified during follows of Great Egrets and Snowy Egrets. More than half of the foraging sites were located within impounded habitat (Table 4). When forested wetlands were included in the analysis, both species had selection ratios greater than one for impounded and estuarine habitats and less than one for unimpounded habitat at all spatial scales (with the exception of impounded habitat for Great Egrets at the five $\mathrm{km}$ radius; Fig. 2). Great Egrets showed avoidance of unimpounded habitat at the two larger spatial scales but not at the smallest scale; Snowy Egrets showed avoidance of unimpounded habitat at both the largest and smallest spatial scales, and selection for impounded habitat at the largest spatial scale (Fig. 2). These patterns of habitat selection and avoidance largely disappeared when forested wetlands were excluded form the analysis (Fig. 2).

\section{DISCUSSION}

Colonial nesting Great Egrets and Snowy Egrets showed evidence of habitat selection, but patterns were dependent on the scale of the analysis and the decision to include or exclude forested wetlands. The challenge in assessing habitat selection in animals due to uncertainty over the designation of what habitat is available is well-known (Johnson 1980; Alldredge and Ratti 1986; McClean et al. 1998; Manly et al. 2002), and ardeids are no exception (e.g., Custer and Osborn 1978; Fasola and Barbieri 1978; Gibbs and Kinkel 1997). Resource selection ratios are an improvement over previous measures of habitat selection because the relative order and proportions of categories do not change when categories are added or removed from the available list (Manly et al. 2002). However, despite this improvement, choices of what to in- clude within habitat categories can still affect the outcome of selection analysis. Our results caution researchers against arbitrarily including or excluding habitat within categories at various scales, as it may lead to incorrect interpretations of resource selection, including placing undue importance on some habitat types. In such cases it may be beneficial to present results of analyses both with and without the questionable habitat included within categories, to reflect the uncertainty in the information on habitat selection.

One explanation for scale-dependent patterns of foraging habitat selection in nesting ardeids is that decisions made at the broadest spatial scale can limit choices at more local scales (Johnson 1980). This may explain the lack of habitat selection by ardeids when forested wetlands were excluded from the analysis. In the northern Indian River Lagoon estuary watershed, area of forested wetlands increased with distance from colony sites, and egrets appeared to have selected colony sites that were surrounded by abundant suitable foraging habitat (e.g., salt and freshwater marsh). Once habitat selection was made at the coarse-level (i.e., colony site selection), finer-scale habitat selection near colonies (within the birds energetically optimal flight radius) was determined by factors such as water depth, prey density, and the interspersion of habitats (Stolen 2006). Managers should consider scale when evaluating evidence for preferential foraging habitat use in the areas surrounding ardeid nesting colonies.

The degree to which Great Egrets and Snowy Egrets forage socially varies widely between studies (e.g., Smith 1995b; Custer and Galli 2002; Custer et al. 2004). Most of the Great Egrets and Snowy Egrets followed landed at sites with other wading birds present, demonstrating the high level of social foraging under the conditions in the study area (see Stolen 2006). The benefits of joining a group might be associated with locating prey resources (Krebs 1974; Hafner et al. 1998), or improved foraging success of group foraging individuals (Caldwell 1981; Hafner et al. 1982; Cezilly et al. 1990; Master et al. 1993; Stolen 2006). Joining groups 


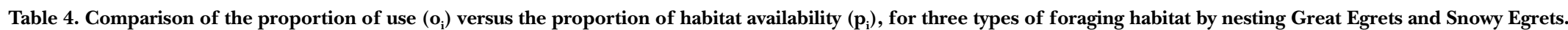

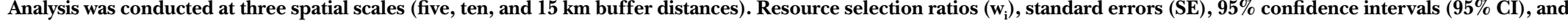
Manly's standardized selection ratio $\left(B_{i}\right)$ are given for analyses with and without forested wetland. All calculations based on methods in Manly $e$ al. (2002).

\begin{tabular}{|c|c|c|c|c|c|c|c|c|c|c|c|c|c|c|}
\hline & \multicolumn{7}{|c|}{ Great Egret } & \multicolumn{7}{|c|}{ Snowy Egret } \\
\hline & $\mathrm{N}$ & $\mathrm{o}_{\mathrm{i}}$ & $\mathrm{p}_{\mathrm{i}}$ & $\mathrm{w}_{\mathrm{i}}$ & $\mathrm{SE}$ & $95 \% \mathrm{CI}$ & $\mathrm{B}_{\mathrm{i}}$ & $\mathrm{N}$ & $\mathrm{o}_{\mathrm{i}}$ & $\mathrm{p}_{\mathrm{i}}$ & $\mathrm{w}_{\mathrm{i}}$ & $\mathrm{SE}$ & $95 \% \mathrm{CI}$ & $\mathrm{B}_{\mathrm{i}}$ \\
\hline \multicolumn{15}{|c|}{$15 \mathrm{~km}$ forested wetlands included } \\
\hline Impounded & 15 & 0.38 & 0.54 & 1.43 & 0.25 & $(0.82,2.03)$ & 0.39 & 19 & 0.41 & 0.61 & 1.49 & 0.21 & $(0.98,2.00)$ & 0.41 \\
\hline Un-Impounded & 5 & 0.47 & 0.18 & 0.38 & 0.16 & $(0.01,0.75)$ & 0.11 & 8 & 0.51 & 0.26 & 0.51 & 0.15 & $(0.14,0.87)$ & 0.14 \\
\hline Estuarine & 8 & 0.16 & 0.29 & 1.81 & 0.54 & $(0.52,3.11)$ & 0.50 & 4 & 0.08 & 0.13 & 1.66 & 0.78 & $(0.00,3.52)$ & 0.45 \\
\hline \multicolumn{15}{|c|}{$10 \mathrm{~km}$ forested wetlands included } \\
\hline Impounded & 14 & 0.43 & 0.54 & 1.26 & 0.23 & $(0.71,1.81)$ & 0.35 & 18 & 0.47 & 0.60 & 1.28 & 0.19 & $(0.82,1.73)$ & 0.36 \\
\hline Un-Impounded & 4 & 0.41 & 0.15 & 0.37 & 0.17 & $(0.00,0.79)$ & 0.11 & 8 & 0.45 & 0.27 & 0.59 & 0.18 & $(0.16,1.02)$ & 0.17 \\
\hline Estuarine & 8 & 0.16 & 0.31 & 1.92 & 0.56 & $(0.57,3.27)$ & 0.54 & 4 & 0.08 & 0.13 & 1.69 & 0.79 & $(0.00,3.57)$ & 0.47 \\
\hline \multicolumn{15}{|c|}{$5 \mathrm{~km}$ forested wetlands included } \\
\hline Impounded & 4 & 0.45 & 0.44 & 0.98 & 0.36 & $(0.11,1.85)$ & 0.30 & 14 & 0.51 & 0.67 & 1.31 & 0.20 & $(0.82,1.79)$ & 0.40 \\
\hline Un-Impounded & 2 & 0.35 & 0.22 & 0.64 & 0.40 & $(0.00,1.59)$ & 0.19 & 4 & 0.39 & 0.19 & 0.49 & 0.22 & $(0.00,1.01)$ & 0.15 \\
\hline Estuarine & 3 & 0.20 & 0.33 & 1.69 & 0.80 & $(0.00,3.60)$ & 0.51 & 3 & 0.10 & 0.14 & 1.44 & 0.77 & $(0.00,3.29)$ & 0.45 \\
\hline \multicolumn{15}{|c|}{$15 \mathrm{~km}$ forested wetlands not included } \\
\hline Impounded & 15 & 0.49 & 0.54 & 1.10 & 0.19 & $(0.64,1.56)$ & 0.38 & 19 & 0.57 & 0.61 & 1.07 & 0.15 & $(0.70,1.43)$ & 0.37 \\
\hline Un-Impounded & 5 & 0.24 & 0.18 & 0.74 & 0.30 & $(0.02,1.46)$ & 0.26 & 8 & 0.28 & 0.26 & 0.91 & 0.28 & $(0.25,1.58)$ & 0.32 \\
\hline Estuarine & 8 & 0.27 & 0.29 & 1.05 & 0.32 & $(0.30,1.81)$ & 0.36 & 4 & 0.14 & 0.13 & 0.90 & 0.42 & $(0.00,1.91)$ & 0.31 \\
\hline \multicolumn{15}{|c|}{$10 \mathrm{~km}$ forested wetlands not included } \\
\hline Impounded & 14 & 0.53 & 0.54 & 1.02 & 0.19 & $(0.58,1.47)$ & 0.35 & 18 & 0.61 & 0.60 & 0.98 & 0.15 & $(0.63,1.33)$ & 0.32 \\
\hline Un-Impounded & 4 & 0.22 & 0.15 & 0.70 & 0.32 & $(0.00,1.48)$ & 0.24 & 8 & 0.25 & 0.27 & 1.05 & 0.32 & $(0.29,1.81)$ & 0.35 \\
\hline Estuarine & 8 & 0.25 & 0.31 & 1.21 & 0.36 & $(0.36,2.06)$ & 0.41 & 4 & 0.13 & 0.13 & 1.00 & 0.47 & $(0.00,2.12)$ & 0.33 \\
\hline \multicolumn{15}{|c|}{$5 \mathrm{~km}$ forested wetlands not included } \\
\hline Impounded & 4 & 0.55 & 0.44 & 0.81 & 0.30 & $(0.09,1.53)$ & 0.23 & 14 & 0.66 & 0.67 & 1.01 & 0.16 & $(0.64,1.38)$ & 0.34 \\
\hline Un-Impounded & 2 & 0.14 & 0.22 & 1.57 & 0.98 & $(0.00,3.92)$ & 0.45 & 4 & 0.17 & 0.19 & 1.12 & 0.50 & $(0.00,2.32)$ & 0.38 \\
\hline Estuarine & 3 & 0.31 & 0.33 & 1.08 & 0.51 & $(0.00,2.29)$ & 0.31 & 3 & 0.17 & 0.14 & 0.85 & 0.46 & $(0.00,1.95)$ & 0.29 \\
\hline
\end{tabular}




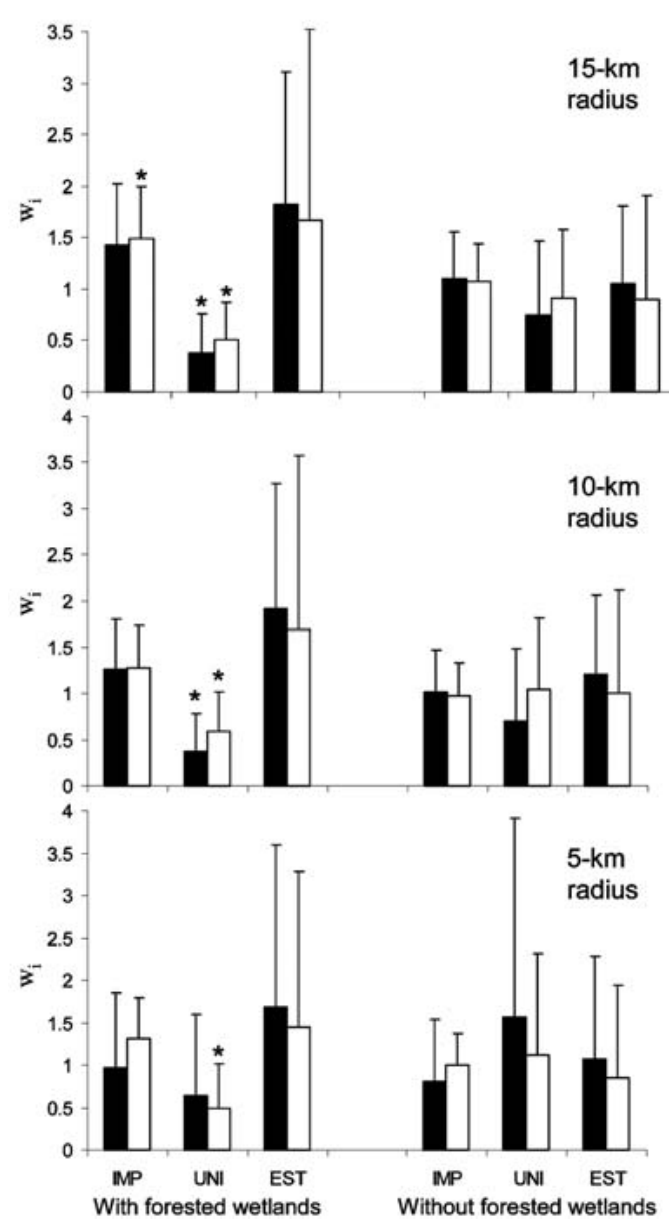

Figure 2. Resource selection ratios for Great Egret (black bars) and Snowy Egret (white bars) foraging habitat, based on follows from colonies. Selection ratios are displayed by habitat type (error bars show $95 \%$ confidence limits), for analyses with and without forested wetland habitats included, for three concentric radii of distances from colonies. Bars marked with * show evidence of selection or avoidance of habitat type at an overall $\alpha=0.05$. IMP $=$ impounded habitat, UNI = unimpounded habitat, EST = estuarine edge habitat.

might have been facilitated by the tendency of the Great Egrets and Snowy Egrets to travel to foraging sites in groups. Group flights from nesting colonies appears to vary widely between sites with some authors reporting levels lower than in this study (e.g., Erwin 1983,1984; MacCarone and Parsons 1988; Smith 1995a).

Previous studies of ardeid foraging flights have suggested that the availability of foraging habitat surrounding the colonies is an important component in the protection of wading bird nesting colonies. Nesting ardeids often switch foraging habitats rapidly in response to changes in hydrology (Smith 1995a; Smith and Collopy 1995; Custer et al. 2004). Therefore, protecting a mix of different wetland types within flight distance of colonies is prudent because unpredictable disturbances may affect some types but not others. This study suggested that such a level of protection, including contingencies for fluctuations/changes in habitat conditions, could be met by protecting a variety of wetland habitats within $15 \mathrm{~km}$ of the nesting colonies of Great Egrets and Snowy Egrets in the northern Indian River Lagoon estuary. The range of conditions described in this and other studies highlights the flexibility in foraging behavior of these species, but also underscores the value of gathering systemspecific information to help guide management decisions on their behalf.

\section{ACKNOWLEDGMENTS}

Dr. W. Knott III (retired), Chief of the Biological Sciences Branch, B. Summerfield, Chief of Center Operations, K. Gorman, and D. Doerr at the Kennedy Space Center, Florida, provided support during all phases of this study. G. Carter, P. Frederick, W. Kitchens, C. Montague, and K. Hobson provided helpful suggestions on the manuscript. We thank the NASA Aircraft Operations pilots for their patience and aerial excellence. We acknowledge the staff of the Merritt Island National Wildlife Refuge for granting permission to conduct this work on the refuge. This study was conducted under NASA contract NAS10-02001. This is contribution 6 from the Wetlands Initiative at Merritt Island National Wildlife Refuge.

\section{LiTERATURE Cited}

Alldredge, J. R. and J. T. Ratti. 1986. Comparison of some statistical techniques for analysis of resource selection. Journal of Wildlife Management 50: 157165.

Anonymous. 1999. Digital Orthographic QuarterQuads (1999). Florida Department of Environmental Protection. http://data.labins.org/2003/index. cfm. Accessed August 2004.

Anonymous. 2002. SJRWMD Land Use and Land Cover (2000). St. Johns River Water Management District. http://www.sjrwmd.com/programs/data.html. Accessed October 2004.

Bancroft, G. T., A. M. Strong, R. J. Sawicki, W. Hoffman and S. D. Jewell. 1994. Relationships among wading bird foraging patterns, colony locations, and hydrology of the Everglades. Pages 615-687 in Everglades: The Ecosystem and its Restoration (S. M. Davis and J. C. Ogden, Eds.). St. Lucie Press, Delray Beach, FL. 
Brockmeyer, R. E., J. R. Rey, R. W. Virnstein, R. G. Gilmore and L. Earnest. 1997. Rehabilitation of impounded estuarine wetlands by hydrologic reconnection to the Indian River Lagoon, Florida (USA). Wetlands Ecology and Management 4: 93-109.

Caldwell, G. S. 1981. Attraction to tropical mixed-species heron flocks: proximate mechanism and consequences. Behavioral Ecology and Sociobiology 8: 99103.

Cezilly, F., V. Boy and H. Hafner. 1990. Group foraging in Little Egrets (Egretta grazetta): from field evidence to experimental investigation. Behavioural Processes 21: 69-80.

Conover, W. J. 1980. Practical Nonparametric Statistics. Second edition. John Wiley and Sons, New York.

Custer, C. M. and J. Galli. 2002. Feeding habitat selection by Great Blue Herons and Great Egrets nesting in east central Minnesota. Waterbirds 25: 115-124.

Custer, C. M., S. A. Suarez and D. A. Olsen. 2004. Feeding habitat characteristics of the Great Blue Heron and Great Egret nesting along the upper Mississippi River, 1995-1998. Waterbirds 27: 454-468.

Custer, T. W. and R. G. Osborn. 1978. Feeding habitat use by colonially-breeding herons, egrets, and Ibises in North Carolina. Auk 95: 733-743.

Dall, S. R. X., L. A. Giraldeau, O. Olsson, J. M. McNamara and D. W. Stephens. 2005. Information and its use by animals in evolutionary ecology. Trends in Ecology and Evolution 20: 187-193.

Erwin, R. M. 1983. Feeding habitats of nesting wading birds: spatial use and social influences. Auk 100: 960970.

Erwin, R. M. 1984. Feeding flights of nesting wading birds at a Virginia colony. Colonial Waterbirds 7: 7479.

Erwin, R. M., G. M. Sanders and D. J. Prosser. 2005. Changes in lagoonal marsh morphology at selected Northeastern Atlantic coast sites of significance to migratory waterbirds. Wetlands 24: 891-903.

Fasola, M. and F. Barbieri. 1978. Factors affecting the distribution of heronries in northern Italy. Ibis 120 : 537-540.

Frederick, P. C. and M. W. Collopy. 1989. Nesting success of five ciconiiform species in relation to water conditions in the Florida Everglades. Auk 106: 625634.

Gibbs, J. P. 1991. Spatial relationships between nesting colonies and foraging areas of Great Blue Herons. Auk 108: 764-770.

Gibbs, J. P. and L. K. Kinkel. 1997. Determinants of the size and location of Great Blue Heron colonies. Colonial Waterbirds 20: 1-7.

Hafner, H., V. Boy and G. Gory. 1982. Feeding methods, flock size, and feeding success in the Little Egret Egretta garzetta and the Squacco Heron Ardeola ralloides in Camargue, southern France. Ardea 70: 4554.

Hafner, H., P. J. Dugan, M. Kersten, O. Pineau and J. P. Wallace. 1993. Flock feeding and food intake in Litthe Egrets Egretta grazetta and their effects on food provisioning and reproductive success. Ibis 135: 2532.

Hafner, H., Y. Kayser, V. Boy, M. Fasola, A. Julliard, R. Pradel and F. Cezilly. 1998. Local survival, natal dispersal, and recruitment in Little Egrets Egretta grazetta. Journal of Avian Biology 29: 216-227.

Hancock, J. and J. A. Kushlan. 1984. The Herons Handbook. Croom Helm Ltd., Kent, UK.
Jakubas, D. 2004. The response of the Grey Heron to a rapid increase in round goby. Colonial Waterbirds 27: 304-307.

Johnson, D. H. 1980. The comparison of usage and availability measurements for evaluating resource preference. Ecology 61: 65-71.

Kersten, M., R. H. Britton, P. J. Dugan and H. Hafner. 1991. Flock feeding and food intake in Little Egrets: the effects of prey distribution and behavior. Journal of Animal Ecology 60: 241-252.

Krebs, J. R. 1974. Colonial nesting and social feeding as strategies for exploiting food resources in the Great Blue Heron (Ardea herodias). Behaviour 51: 99-134.

Kushlan, J. A. 1997. The conservation of wading birds. Colonial Waterbirds 20: 129-137.

Larson, V. L. 1992. A method for assessing the conservation value of natural communities at a local scale. Florida Institute of Technology, Melbourne, Florida.

Lombardini, K., R. E. Bennetts and C. Tourenq. 2001. Foraging success and foraging habitat use by Cattle Egrets and Little Egrets in the Camargue, France. Condor 103: 38-44.

MacCarone, A. D. and K. C. Parsons. 1988. Differences in flight patterns among nesting ibises and egrets. Colonial Waterbirds 11: 67-71.

Manly, B. F. J., L. L. McDonald, D. L. Thomas, T. L. McDonald and W. P. Erickson. 2002. Resource Selection by Animals. Kluwer Academic Publishers, Dorderecht.

Master, T. L., M. Frankel and M. Russell. 1993. Benefits of foraging in mixed-species wader aggregations in a southern New Jersey salt marsh. Colonial Waterbirds 16: 149-157.

McClean, S. A., M. A. Rumble, R. M. King and W. L. Baker. 1998. Evaluation of resource selection methods with different definitions of availability. Journal of Wildlife Management 62: 793-801.

Ogden, J. C. 1994. A comparison of wading bird nesting colony dynamics (1931-1946 and 1974-1989) as an indication of ecosystem conditions in the southern Everglades. Pages 533-570 in Everglades: The Ecosystem and its Restoration (S. M. Davis and J. C. Ogden, Eds.). St. Lucie Press, Delray Beach, Florida.

Palmer, R. S. 1962. Handbook of North American birds. Volume 1.Yale University Press, New Haven, Connecticut.

Schikorr, K. E. and H. M. Swain. 1995. Wading birds - barometer of management strategies in the Indian River Lagoon. Bulletin of Marine Science 57: 215-229.

Schmalzer, P. A. 1995. Biodiversity of saline and brackish marshes of the Indian River Lagoon: historic and current patterns. Bulletin of Marine Science 57: 37-48.

Sewell, C. E., N. D. Joiner, M. S. Robson and M. J. Weise. 1995. Wading bird colony protection in the Indian River Lagoon. Bulletin of Marine Science 57: 237-241.

Smith, J. P. 1995a. Foraging flights and habitat use of nesting wading birds (Ciconiiformes) at Lake Okeechobee, Florida. Colonial Waterbirds 18: 139-158.

Smith, J. P. 1995b. Foraging sociability of nesting wading birds (Ciconiiformes) at Lake Okeechobee, Florida. Wilson Bulletin 107: 437-451.

Smith, N. P. 1987. Introduction to the tides of Florida's Indian River Lagoon. I. water levels. Florida Scientist 50: 49-61.

Smith, N. P. 1993. Tidal and wind-driven transport between Indian River and Mosquito Lagoon, Florida. Florida Scientist 56: 235-246.

Smith, J. P. and M. W. Collopy. 1995. Colony turnover, nest success and productivity, and causes of nest fail- 
ure among wading birds (Ciconiiformes) at Lake Okeechobee, Florida (1989-1992). Archiv für Hydrobiologie. Special Issues. Advances in Limnology 45: 287-316.

Smith, R. B. and D. R. Breininger. 1995. Wading bird populations of the Kennedy Space Center. Bulletin of Marine Science 57: 230-236.

Stolen, E. D. 2006. Habitat selection and foraging success of wading birds in impounded wetlands in Florida. Ph.D. Dissertation, University of Florida, Gainesville.
Stolen, E. D., D. R. Breininger, and P. C. Frederick. 2005. Using waterbirds as indicators in estuarine systems: successes and perils. Pages 409-422 in Estuarine Indicators (S. A. Bortone, Ed.). CRC Press, Boca Raton, FL.

Stolen, E. D., R. B. Smith, and D. R. Breininger. 2002. Analysis of wading bird use of impounded wetland habitat on Kennedy Space Center/Merritt Island National Wildlife Refuge 1987-1997. NASA Technical Memorandum 211173. Kennedy Space Center, FL. 